\title{
TRADISI UMPAN KAMPUNG BAGI MASYARAKAT DI DUSUN TEMURAK DESA MELIAU HILIR KABUPATEN SANGGAU
}

\author{
Rosianti, Sri Buwono \\ Program Studi Pendidikan Ilmu Pengetahuan Sosial FKIP Untan Pontianak \\ Email: rosianti0807@student.untan.ac.id
}

\begin{abstract}
This study aims to determine the noble values of a tradition that implied in Umpan Kampung Tradition that carried out by the community in Temurak Hamlet, Meliau Hilir Village, Meliau District, Sanggau Regency. This study used descriptive qualitative method which used field observation, interviews with local community of Temurak village, and documentation. Sources of the data that are used by the researcher were primary data and secondary data. The technique of data collection through three stages, they were: data reduction, data presentation, and making conclusion. The finding of this study showed that: the background of Umpan Kampung Tradition in Temurak Hamlet, Meliau Hilir Village, Meliau District, Sanggau Regency is to express the feeling of gratitude for the sustenance that has been received by the community. The process of Umpan Kampung Tradition started with the preparation and ended with the implementation of Umpan Kampung ceremony itself. The noble values that conveyed in the Umpan Kampung tradition are the value of deliberation, the value of mutual cooperation, the value of togetherness, the value of solidarity, and the value of religion
\end{abstract}

Keywords: The Noble Values, Umpan Kampung Tradition, Culture.

\section{PENDAHULUAN}

Kebudayaan merupakan kata budaya dalam bentuk jamak dari kata "budi" dan "daya" yang berarti cinta, karsa, dan rasa. Kata "budaya" berasal dari bahasa Sansekerta, buddhayah, merupakan bentuk jamak kata buddhi yang berarti budi atau akal. Dalam bahasa inggris, kata budaya berasal kata culture. Menurut Tylor kebudayaan merupakan "peradaban yang mengandung pengertian yang luas meliputi pemahaman perasaan suatu bangsa yang kompleks" (Aminuyati,2019,p.93).

Sedangkan pengertian dari tradisi. nenurut Darwis (Darwis, 2017) tradisi merupakan adat istiadat yang dilahirkan oleh manusia, namun lebih mengarah kepada kebiasaan yang umumnya bersifat supranatural yang di dalamnya meliputi nilai budaya, norma-norma dalam masyarakat, hukum dan aturan yang berkaitan.

Nilai-nilai luhur dipahami oleh orang dalam berperilaku guna mewujudkan nilainilai baik. Tujuan manusia berperilaku baik hakikatnya adalah ingin mencapai dan mewujudkan nilai-nilai luhur yang ada di dalamnya.

Masyarakt Dusun Temurak memiliki tradisi yang masih dilaksanakan hingga saat ini yaitu tradisi Umpan Kampung. Tradisi Umpan Kampung dilakukan untuk menyampaikan rasa ucapan syukur kepada Pedagi Mangku Kamit yang sudah memberikan rezeki dan juga memohon agar diberikan perlindungan dari segala marabahaya baik dalam hal yang gaib maupun yang bersifat fisik seperti sakit penyakit. Tradisi ini melibatkan seluruh masyarakat di dusun Temurak, seperti warga dusun, kemudian para tetua 
kampung, dan ketua adat di dusun Temurak.

Kepercayaan dan keyakinan masyarakat Dusun Temurak terhadap tradisi Umpan Kampung relatif berbedabeda, diketahui bahwa tidak semua masyarakat begitu meyakini tradisi Umpan Kampung itu sendiri dikarenakan mereka sudah memiliki kepercayaan atau keyakinan terhadap Tuhan atau sudah memiliki agama. Alasan masyarakat yang sudah beragama masih tetap melaksanakan tradisi Umpan Kampung ini adalah wujud dari menghargai tradisi yang memang susah ada sejak dulu. Beberapa masyarakat yang tidak menganut kepercayaan agama apapun, salah satunya seperti sesepuh yang ada di Dusun Temurak dan masih hidup hingga saat ini, para sesepuh itu masih sangat meyakini tradisi Umpan Kampung ini dimana para sesepuh masih meminta untuk diberikan berkah berupa kesehatan dan perlindungan dari segala mara bahaya kepada sesuatu yang sakral yang disebut dengan Pedagi Mangkuk Kamit.

Tradisi Umpan Kampung masih bertahan hingga saat ini karena masyarakat sangat menghargai tradisi ini yang sudah ada sebelum masyarakat memiliki agama atau dikenal dengan kepercayaan dinamisme, yakni kepercayaan bahwa segala sesuatu punya tenaga atau kekuatan yang dapat mempengaruhi keberhasilan atau kegagalan usaha manusia. Adapun tradisi tersebut selalu dilaksanakan setiap satu tahun sekali oleh seluruh masyarakat di Dusun Temurak.

Alasan peneliti meneliti mengenai tradisi Umpan Kampung ini adalah supaya peneliti bisa mengetahui mengenai latar belakang kemudian, bagaimana proses pelaksanaan, dan bisa mengetahui nilainilai luhur sebuah tradisi yang terkandung dalam tradisi Umpan Kampung. Dari penjelasan sebelumnya peneliti tertarik untuk melakukan penelitian dengan judul "Tradisi Umpan Kampung Bagii Masyarakat Dusun Temurak Desa Meliau Hilir Kecamatan Meliau Kabupaten
Sanggau".Tujuan dari penelitian ini adalah mengetahui dan mendeskripsikan latar belakang tradisi Umpan Kampung di Dusun Temurak Desa Meliau Hilir Kecamatan Meliau Kabupaten Sanggau, mengetahui Proses pelaksanaan tradisi Umpan Kampung di Dusun Temurak Desa Meliau Hilir Kecamatan Meliau Kabupaten Sanggau, mengetahui dan mendeskripsikan Nilai-nilai Luhur sebuah tradisi yang terkandung dalam tradisi Umpan Kampung di Dusun Temurak Desa Meliau Hilir Kecamatan Meliau Kabupaten Sanggau

Tradisi atau kebiasaan, dalam pengertian yang paling sederhana ialah sesuatu yang telah dilakukan sejak lama dan menjadi bagian dari kehidupan di dalam kelompok masyarakat. Hanafi ( dalam Juliana, 2017) mengatakan bahwa sebuah tradisi (turats) merupakan segala warisan masa lampau (baca tradisi) yang masuk pada kita dan masuk kedalam kebudayaan yang sekarang berlaku. Menurut Darwis (2017), tradisi merupakan adat istiadat yang dilahirkan oleh manusia, namun lebih mengarah kepada kebiasaan yang umumnya bersifat supranatural yang di dalamnya meliputi nilai-nilai budaya, norma-norma, hukum dan aturan yang berkaitan.

Kata "kebudayaan" berasal dari (bahasa sansekerta) buddhayah yang merupakan bentuk jamak kata "buddhi" yang berarti budi atau akal. Kebudayaan diartikan sebagai "hal-hal yang bersangkutan dengan budi atau akal". Sejalan dengan pendapat Tylor (dalam Soelaeman, 2010) yang mengatakan bahwa "Kebudayaan adalah kompleks yang mencangkup pengetahuan, kepercayaan, kesenian, moral, hukum, adat istiadat dan lain kemampuan-kemampuan serta kebiasaan-kebiasaan yang didapatkan oleh manusia sebagai anggota masyarakat" Menurut Koentjaraningrat (dalam Julian, 2017) ada 3 wujud kebudayaan yakini wujud kebudayaan sebagai kompleks dari ide-ide, gagasan, nilai-nilai, norma-norma, peraturan dan sebagainya, Wujud kebudayaan sebagai suatu kompleks dari 
ide-ide, gagasan, tindakan berpola dari manusia dalam masyaraka, dan Wujud kebudayaan sebagai benda-benda hasil karya manusia.

Herabudin mengungkapkan bahwa nilai adalah kualitas suatu hal yang menjadikan sesuatu disukai, dihargai, diinginkan, berguna, atau dapat dijadikan objek kepentingan. Nilai memberi makna bagi hidup, lebih dari sekedar keyakinan dan selalu menyangkut perbuatan atau tindakan.(Herabudin, 2014). Terkait dengan nilai-nilai luhur Nurfadillah (2014) mengatakan bahwa: usaha-usaha yang dilakukan dalam mengembangkan nilainilai luhur sebuah tradisi antara lain,

"mengembangkan nilai-nilai moral yang dilandasi nilai-nilai dalam agama, mengembangkan sikap saling menghargai dan menghormati antar sesama, mengembangkan cara hidup tolong menolong dalam kebersamaan, mengembangkan sikap peduli antar sesama masyarakat, dan menjunjung tinggi nilai-nilai yang terkandung dalam sebuah tradisi".

\section{METODE PENELITIAN}

Metode penelitian dalam penelitian ini menggunakan penelitian kualitatif. Menurut Sugiyono (dalam Sugiyono, 2020) metode penelitian kualitatif adalah metode penelitian yang digunakan untuk meneliti pada kondisi objek yang alamiah, (sebagai lawannya adalah eksperimen) dimana peneliti sebagai instrumen kunci. Adapun lokasi penelitian ini adalah di Dusun Temurak Desa Meliau Hilir Kecamatan Meliau Kabupaten Sanggau.

\section{Sumber Data}

Dalam penelitian ini menggunakan dua sumber data yaitu data primer dan data sekunder. Data primer yakini berupa data wawancara dengan tokoh masyarakat di Dusun Temurak Desa Meliau Hilir Kecamatan Meliau Kabupaten Sanggau.. Data sekunder merupakan data yang diperoleh secara tidak langsung, sehingga data yang digunakan bertujuan mendukung data primer yaitu dengan mengunakan studi kepustakaan, dokumentasi, buku, jurnal, arsip tertulis yang berhubungan dengan objek yang akan diteliti dalam penelitian ini. Adapun sumber data sekunder dalam penelitian ini adalah hasil dokumentasi dari tradisi Umpan Kampung yang ada di Dusun Temurak. Informan dalam penelitian ini berjumlah lima informan . Data informan penelitian ini adalah informan pertama yaitu bapak Makarius Suparno yang berumur 49 tahun selaku Kepala Dusun Temurak, informan kedua bapak Yakobus Seran yang berumur 72 tahun selaku tetua adat di Dusun Temurak, informan ketiga bapak Otoi yang berumur 55 tahun selaku ketua adat di Dusun Temurak, informan keempat bapak Selimin berumur 44 tahun selaku dukun di Dusun Temurak, dan informan kelima bapak Cosmos Dionadi berumur 37 tahun selaku ketua pemuda di Dusun Temurak.

\section{Teknik dan Alat Pengumpulan Data}

Agar bahan dan keterangan serta informasi yang diperoleh dari sumber data yang benar dan tepat, peneliti menggunakan beberapa teknik pengumpulan data yakini observasi, wawancara, dan dokumentasi. Sedangkan alat pengumpulan data yang digunakan adalah pedoman observasi, pedoman wawancara, dan dokumentasi berupa arsipan data, foto-foto, dan alat perekam seperti handphone.

\section{Teknik Analisis Data}

Menurut Miles dan Huberman (dalam Sugiyono,2019) dibagi menjadi tiga alur kegiatan yaitu data reduction (reduksi data), data display (penyajian data), dan conclusion drawing/verification (menarik kesimpulan dan verifikasi) 


\section{Teknik Pengujian Keabsahan Data}

Triangulasi dalam pengujian keabsahan data menurut Sugiyono (2019) diartikan sebagai pengecekan data dari berbagai sumber dengan berbagai cara, dan berbagai waktu, dengan demikian terdapat triangulasi sumber, triangulasi teknik pengumpulan data, dan waktu. Peneliti hanya menggunakan dua bagian triangulasi yaitu triangulasi sumber dan triangulasi teknik. Triangulasi sumber bertujuan untuk menguji kredibilitas data dengan cara mengecek data yang telah diperoleh melalui beberapa sumber. Data diperoleh wawancara. Sedangkan triangulasi teknik bertujuan untuk menguji kredibilitas data dilakukan dengan cara mengecek data kepada sumber yang sama dengan teknik berbeda. Data diperoleh dengan wawancara, kemudian dicek kembali dengan observasi dan dokumentasi.

\section{HASIL PENELITIAN DAN PEMBAHASAN}

\section{Hasil}

Latar Belakang Tradisi Umpan Kampung di Dusun Temurak Desa Meliau Hilir Kecamatan Meliau Kabupaten Sanggau

Berdasarkan data yang diperoleh dari kepala Dusun Temurak jumlah penduduk pada tahun 2020 yang ada di Dusun Temurak yakini RT 01 berjumlah 68 kepala keluarga dengan jumlah jiwa sebanyak 230 jiwa, sedangkan RT 02 berjumlah 46 kepala keluarga dengan jumlah jiwa sebanyak 187 jiwa.

Tradisi Umpan Kampung merupakan suatu tradisi yang ada di Dusun Temurak yang dilaksanakan sebagai suatu ungkapan rasa syukur masyarakat kepada Pedagi Mangku Kamit. Tidak hanya sebagai ungkapan rasa syukur tradisi Umpan Kampung juga dilaksanakan dengan tujuan meminta perlindungan bagi masyarakat kampung dari segala marabahaya baik dalam hal yang gaib maupun yang bersifat fisik seperti sakit penyakit. Tradisi ini dilakukan dengan cara memberikan sesajen kepada Pedagi Mangku Kamit yang dianggap sakral dan memiliki kekuatan untuk memberi perlindungan dan kesembuhan. Tradisi ini juga melibatkan seluruh warga masyarakat dusun Temurak. Berdasarkan observasi yang dilakukan ke Pulau Belumbak yang terletak ditengah Sungai Kapuas. Pulau Belumbak ini adalah tempat dilakukannya tradisi Umpan Kampung. Pulau Belumbak masih merupakan kawasan hutan yang masih terjaga kelestariannya. Di Pulau Belumbak ini terdapat sesuatu yang sakral yakni yang disebut masyarakat sebagai Pedagi Mangku Kamit (Pedagi Guna).

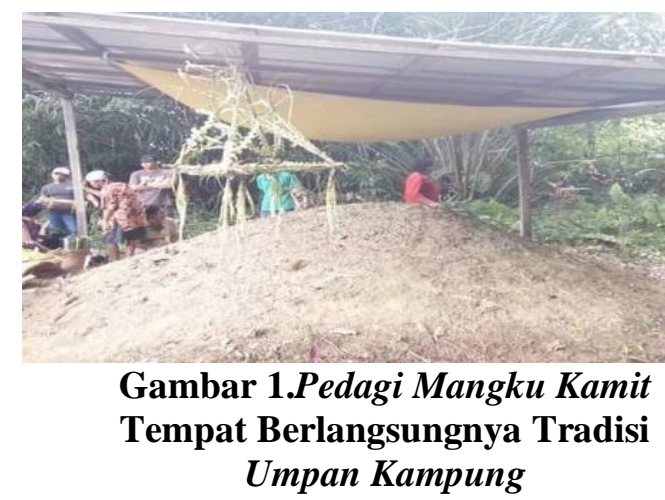

Bentuk fisik dari Pedagi Mangku Kamit ini yaitu sebuah gundukan tanah yang membentuk seperti kerucut tingginya sekitar 1,5 meter kemudian lebarnya sekitar 2 meter. Peneliti mendapatkan latar belakang terjadinya tradisi Umpan Kampung terbentuk karena Pada masa itu masyarakat belum mengenal adanya ajaran agama jadi para nenek moyang masih menganut kepercayaan kepada roh -roh leluhur atau dikenal dengan kepercayaan animisme. Tradisi Umpan Kampung dilakukan sebagai ungkapan rasa syukur kepada Tuhan atas segala berkat, rezeki dan kesehatan yang telah diberikan dengan melalui perantara yakni Pedagi Mangku Kamit yang dianggap masyarakat sebagai Keramat Dolak atau dianggap utusan Tuhan seperti dewa-dewa, yang menjadi tempat untuk berdoa, meminta rezeki,kesehatan dan pengobatan secara 
tradisional. Tradisi Umpan Kampung dilangsungkan setiap tahunya secara turun temurun oleh masyarakat Dusun Temurak.

Pedagi Mangku Kamit ini merupakan benda yang berupa gundukan tanah dianggap sakral. Asal mula dari Pedagi Mangku Kamit adalah diceritakan bahwa dahulu ada sepasang suami istri yang menghilang secara tiba-tiba, namun kemudian mereka datang ke dalam mimpi seseorang yang masih memiliki garis keturunannya dan mengatakan bahwa sepasang suami istri ini tidak lagi tinggal di dunia manusia melainkan sudah tinggal di alam yang berbeda. Sehingga inilah awal mula masyarakat yang pada masa itu memang belum mengenal agama menganggap bahwa Pedagi Mangku Kamit ini sebagai perantara untuk bisa berkomunikasi dengan Sang Pencipta atau dengan kata lain masyarakat pada masa itu menganggap bahwa Pedagi Mangku Kamit merupakan salah satu utusan Tuhan.

Proses Pelaksanaan Tradisi Umpan Kampung di Dusun Temurak Desa Meliau Hilir Kecamatan Meliau Kabupaten Sanggau

Observasi ini setelah melewati berbagai tahap pendekatan, persetujuan, persiapan dalam pelaksanaannya. Dalam proses pelaksanaan tradisi Umpan Kampung terdapat beberapa tahapan yaitu tahap pertama masyarakat mengadakan musyawarah, kemudian tahap kedua yaitu tempat pelaksanaan tradisi Umpan Kampung, tahap ketiga yaitu orang-orang yang ikut serta dalam tradisi Umpan Kampung, tahap keempat yaitu tahap persiapan pelaksanaan tradisi umpan kampung, tahap kelima yaitu tahap pelaksanaan tradisi Umpan Kampung.

\section{a. Masyarakat Mengadakan}

\section{Musyawarah}

Berdasarkan hasil observasi yang dilakukan oleh peneliti di rumah dukun yang juga digunakan untuk melaksanakan persiapan-persiapan untuk melaksanakan tradisi Umpan Kampung. Rapat atau musyawarah ini dilaksanakan untuk membahas hal-hal apa saja yang akan dilakukan pada saat pelaksanaan tradisi Umpan Kampung serta kontribusi yang bisa masyarakat berikan. Pada beberapa tahun sebelumnya para masyarakat diminta untuk mengumpulkan sebanyak empat canting beras ketan dan empat canting beras masyarakat mengenalnya dengan sebutan biris. Namun itu sedikit berbeda sekitar lima tahun belakangan dari hasil rapat yang sudah dilaksanakan secara musyawarah diputuskan bahwa biris yang akan diberikan yakni memberikan uang sebesar RP 25.000 per Kepala Keluarga dan jika dalam pelaksanaan tradisi Umpan Kampung nanti terjadi kekurang dalam pendanaan dan lainnya maka masyarakat akan secara bersama-sama menyumbang sebisa mereka. Selain itu juga biasanya akan ada bantuan dana dari perusahaan sawit dan perusahaan Bauksit yang ada di sekitar daerah tersebut.

\section{b. Tempat Pelaksanaan Tradisi Umpan Kampung}

Berdasarkan hasil observasi yang dilakukan oleh peneliti diketahui bahwa tempat berlangsungnya tradisi Umpan Kampung tidak boleh di sembarang tempat melainkan pemilihan lokasinya memang sudah ditentukan bahkan dari zaman dulu dan tidak berubah hingga saat ini. Tempat dilakukannya tradisi Umpan Kampung terletak di pulau yang ada di tengah Sungai Kapuas. Pulau ini dikenal masyarakat dengan sebutan Pulau Belumbak. Di pulau Belumbak terdapat sesuatu yang dianggap sakral yaitu Pedagi Mangkuk Kamit, sehingga ditempat inilah tradisi Umpan Kampung dilaksanakan.

\section{c. Orang-Orang dalam Tradisi Umpan Kampung di Dusun Temurak}

Berdasarkan hasil observasi yang peneliti lakukan diketahui bahwa orangorang yang ikut serta dalam pelaksanaan tradisi Umpan Kampung yakni, ada dukun yang merupakan seorang yang dituaan dalam lingkungan masyarakat adat di Dusun Temurak, dituakan bukan berarti karena usianya tetapi pemahaman 
penalaran dan kemampuannya dalam memecahkan masalah adat yang ada dalam masyarakat. Kemudian ada pewawang merupakan orang yang akan bertugas mendampingi dukun dan membacakan doa-doa pada saat berlangsungnya tradisi Umpan Kampung. Masyarakat yang ikut serta yaitu masyarakat yang ada di Dusun Temurak dan sekitarnya.

\section{d. Tahap Persiapan Pelaksanaan Tradisi Umpan Kampung di Dusun Temurak}

Berdasarkan observasi yang dilakukan peneliti mengamati bahwa seluruh masyarakat bekerja sama dalam menyiapkan alat dan bahan (peribuh) yang akan digunakan dalam pelaksaan tradisi Umpan Kampung. Diketahui bahwa alat dan bahan (peribuh) yang digunakan adalah adalah ancak,ayam panggang, nasi kuning, kue kecak, telur, par, bubor abang, lutup engkaro, bubor jawak, beras amping, daun kelapa, alat musik gong dan gendang

\section{e. Tahap Pelaksanaan Tradisi Umpan} Kampung

Berdasarkan observasi yang dilakukan peneliti diketahui bahwa pelaksanaan tradisi Umpan Kampung diikuti oleh seluruh warga masyarakat di Dusun Temurak. Adapun tahap pelaksanaannya dalam tradisi Umpan Kampung adalah sebagai berikut :

Setelah selesai dalam tahap persiapan dilanjutkan dengan tahap pelaksanaan. Pada tahap pelaksanaan ini terdapat enam ancak yang telah disiapkan, kemudian ancak tersebut digantung ancak di empat titik yang berbeda yaitu diawali dengan menggantung ancak di hulu kampung, kemudian di hilir kampung, setelah itu di belakang kampung dan yang terakhir di depan kampung. Tujuan hal ini dilakukan adalah supaya kampung dilindungi dari segala sisinya baik itu dari hilir ataupun hulu kampung, maupun dari depan atau belakang kampung. Sehingga bisa terlindungi dari sakit penyakit seperti sampar dan kesulitan rezeki. Sudah empat ancak yang digantung tersisa dua ancak yang masih belum digantung. Kedua ancak ini nantinya akan di gantung di tempat berlangsungnya tradisi Umpan Kampung yakni tempat Pedagi Mangku Kamit berada yaitu di Pulau Belumbak. . Setelah kembali ke kampung seluruh masyarakat melakukan pantang selama tiga hari tiga malam untuk masyarakat bisa sedangkan untuk dukun dan orang yang rumahnya digunakan sebagai tempat melaksanakan tradisi Umpan Kampung melaksanakan pantang selama tujuh hari tujuh malam. Pantangan yang harus dilakukan oleh seluruh masyarakat tanpa terkecuali iyalah, tidak boleh berteriak-teriak, tidak boleh adanya pertengkaran, tidak boleh makan sayur pakis, rebung, jeruk sambal, daun melinjo, dan terasi. Itu adalah beberapa pantangan yang harus dilakukan oleh seluruh masyarakat di Dusun Temurak.

Nilai-Nilai Luhur dalam Tradisi Umpan Kampung di Dusun Temurak Desa Meliau Hilir Kecamatan Meliau Kabupaten Sanggau

Berdasarkan observasi yang dilakukan peneliti mendapatkan beberapa nilai-nilai luhur yang terkandung dalam tradisi Umpan Kampung. Nilai-nilai luhur yang terkandung dalam tradisi Umpan Kampung adalah nilai musyawarah, nilai gotong royong, nilai kebersamaan, nilai solidaritas, dan nilai religius.

Tradisi Umpan Kampung pada hakikatnya merupakan perwujudan rasa bakti dan syukur kepada Tuhan Yang Maha Esa atas apa yang diberikan. Namun karena pada saat itu para nenek moyang belum mengenal adanya ajaran agama para nenek moyang pun melakukan tradisi Umpan Kampung sebagai ungkapan rasa syukur masyarakat terhadap Pedagi Mangku Kamit yang diangga adalah salah satu utusan Tuhan. Berbeda halnya dengan sekarang tradisi Umpan Kampung masih tetap dilaksanakan adalah sebagai bentuk menghargai kearifan lokal yang terdapat di Dusun Temurak Desa Meliau Hilir Kecamatan Meliau Kabupaten Sanggau. 


\section{Pembahasan}

\section{Latar Belakang Tradisi Umpan Kampung Di Dusun Temurak Desa Meliau Hilir Kecamatan Meliau Kabupaten Sanggau}

Tradisi atau kebiasan, dalam pengertian yang paling sederhana adalah sesuatu yang telah dilakukan sejak lama dan dilakukan secara turun temurun. Hal yang paling mendasar dari tradisi ialah informasi yang diteruskan dari generasi ke generasi baik yang tertulis maupun lisan, karena tanpa adanya ini maka tradisi dapat mengalami kepunahan. Dalam pengertian lain tradisi adalah adat istiadat atau sebuah kebiasaan turun temurun yang masih dijalankan oleh masyarakat. Berdasarkan pendapat yang disampaikan Darwis (dalam Darwis, 2017) tradisi yang dilahirkan oleh manusia merupakan adat istiadat, yakni kebiasaan namun lebih ditekankan kepada kebiasaan yang bersifat supranatural yang meliputi dengan nilai-nilai budaya, norma-norma, hukum dan aturan yang berkaitan. Ini sejalan dengan pendapat Darwis yang mengatakan kebiasaan namun lebih ditekankan kepada kebiasaan yang bersifat supranatural selain itu dalam tradisi Umpan Kampung juga mengandung nilai-nilai budaya, norma, dan aturan yang berkaitan didalamnya. Sehingga latar belakang pada tradisi Umpan Kampung terbentuk karena pada masa itu masyarakat belum mengenal adanya ajaran agama jadi mereka masih menganut kepercayaan kepada roh-roh nenek moyang atau biasa kita sebut dengan kepercayaan animisme tradisi umpan kampung dilakukan untuk sebuah ungkapan rasa syukur kepada Tuhan atas segala berkat, rezeki dan kesehatan yang telah diberikan dengan melalui perantara Pedagi Mangku Kamit yang dianggap sebagai Keramat Dolak yakni tempat untuk berdoa, meminta rezeki,kesehatan dan pengobatan secara tradisional. Read \& Andersson (2019) mengatakan bahwa
What they refer to as a cultural trait is more commonly and specifically referred to as a tradition, which may involve beliefs, objects, or customs that are transmitted throught time by being taught by the members of one generation to the members of the next generation (p.330).

Sejalan dengan pendapat Read \& Andersson dalam tradisi Umpan Kampung memiliki latar belakang yang terbentuk karena berasal dari para nenek moyang yang terus dilakukan secara turun temurun dari generasi ke generasi. Dalam tradisi ini melibatkan kepercayaan, yaitu kepada Pedagi Mangku Kamit yang dianggap sakral oleh masyarakat pada masa nenek moyang ,pada saat dahulu para nenek moyang sangat percaya terhadap Pedagi Mangku Kamit. Para nenek moyang beranggapan bahwa Pedagi Mangku Kamit adalah utusan Tuhan maka dari itu para nenek moyang melakukan tradisi Umpan Kampung yang masih berlangsung hingga kini, serta adat istiadat yang juga masih sangat dijaga dari generasi ke generasi.

Tradisi ini dilakukan bukan sematamata karena masyarakat percaya penuh terhadap Pedagi Mangku Kamit melainkan masyarakat menjaga kearifan lokal yang ada di Dusun Temurak agar kearifan lokal ini tidak hilang karena terkikis perkembangan zaman. Selain menjaga kearifan lokal adanya tradisi umpan kampung ini dapat menjadi salah satu cara mengintegrasi masyarakat. Hal ini dapat dilihat dari sikap toleransi sari semua masyarakat dengan agama yang berbedabeda, mereka tetap ikut serta dalam pelaksanaan tradisi Umpan Kampung tanpa memandang agama setiap masyarakatnya.

Proses Pelaksanaan Tradisi Umpan Kampung di Dusun Temurak Desa Meliau Hilir Kecamatan Meliau Kabupaten Sanggau

Tradisi Umpan Kampung ini merupakan tradisi yang wajib dilakukan 
oleh masyarakat di Dusun Temurak setiap setahun sekali. Sebelum pelaksanaan terlebih dahulu masyarakat melakukan musyawarah untuk pelaksanaan tradisi Umpan Kampung. Setelah ancak,ayam panggang, nasi kuning, kue kecak, telur, par, bubor abang, lutup engkaro, bubor jawak, beras amping, daun kelapa, alat musik gong dan gendang hari pelaksanaan ditentukan barulah tahap-tahap selanjutnya dilaksanakan tahapan persiapan dimana masyarakat menyiapkan tempat yang digunakan untuk melaksanakan tradisi Umpan Kampung dan dilanjutkan dengan menyiapkan (peribuh) alat dan bahan yang akan digunakan dalam pelaksanaan tradisi Umpan Kampung adapun alat dan bahannya yakni. Sejalan dengan pendapat yang disampaikan oleh Hasan Hanafi bahwa "tradisi (turats) segala warisan masa lampau (baca tradisi) yang masuk pada kita dan masuk kedalam kebudayaan yang sekarang berlaku"(Juliana, 2017, p.8).

Kegiatan tradisi Umpan Kampung merupakan kegiatan yang berasal dari akal dan budi manusia yang membentuk sebuah kepercayaan, kesenian, dan adat istiadat, serta keseluruhan pengetahuan manusia sebagai makhluk sosial yang digunakan sebagai pedoman dalam bertingkah laku. Adat istiadat yang hadir bersamaan dengan adanya tradisi Umpan Kampung ini digunakan masyarakat sebagai tolak ukur untuk mereka bertingkah laku dalam masyarakat dengan kata lain aturan dalam tradisi Umpan Kampung mampu mengontrol masyarakat agar bertingkah laku sesuai dengan nilai-nilai luhur yang telah diwariskan oleh para nenek moyang kepada generasi penerusnya. Sehingga inilah yang membuat tradisi Umpan Kampung masih terus dilaksanakan hingga saat ini tanpa adanya perubahan di dalam pelaksanaan nya

Nilai-Nilai Luhur dalam Tradisi Umpan Kampung di Dusun Temurak Desa Meliau Hilir Kecamatan Meliau Kabupaten Sanggau

Tradisi Umpan Kampung dilaksanakan oleh masyarakat Dusun Temurak
Kecamatan Meliau Kabupaten Sanggau tidak hanya merupakan sebuah tradisi saha bagi masyarakat, akan tetapi di dalam pelaksanaan tradisi Umpan Kampung mengandung banyak atau kaya akan nilainilai luhur didalamnya. Oleh karena itu tradisi Umpan Kampung perlu dijaga kelestariannya agar masyarakat senantiasa melakukan tradisi tersebut. Berdasarkan hasil pengamatan dan penelitian peneliti, dari proses pelaksanaan tradisi Umpan Kampung dari awal hingga selesai, dapat diungkapkan beberapa nilai-nilai luhur yang melekat dalam proses pelaksanaan tradisi tersebut yakni seperti nilai musyawarah, nilai gotong royong, nilai kebersamaan, nilai solidaritas, dan nilai religius.

Berdasarkan teori diatas dapat dilihat bahwa dalam tradisi Umpan Kampung terdapat nilai-nilai luhur didalamnya dimana hal ini sejalan dengan pendapat yang disampaikan oleh Nurfadillah. Dalam tradisi Umpan Kampung ini masyarakat harus bisa bekerja sama, saling menghargai, tolong menolong agar dalam pelaksanaan tradisi Umpan Kampung bisa berjalan dengan baik dan lancar. Selain itu musyawarah adalah hal yang sangat penting dalam pelaksanaan tradisi Umpan Kampung. Jika tidak adanya musyawarah dalam pelaksanaannya kemungkinan akan terjadinya pertentangan atau pertengkaran dalam masyarakat. Oleh karena itu, musyawarah selalu diadakan terlebih dahulu agar masyarakat mendapatkan keputusan yang tidak akan memberatkan siapa pun melainkan menjadi hal yang akan ditanggung secara bersama-sama.

\section{SIMPULAN DAN SARAN Simpulan}

Berdasarkan hasil penelitian Tradisi Umpan Kampung Bagi Masyarakat Di Dusun Temurak Desa Meliau Hilir.Latar belakang pada tradisi Umpan Kampung dilakukan sebagai ungkapan rasa syukur dari masyarakat kepada roh-roh nenek moyang yang telah memberikan berkat berupa rezeki, kesehatan,dan dijauhkan 
dari hal-hal buruk. Terbentuknya tradisi Umpan Kampung ini terbentuk karena pada masa itu masyarakat Dusun Temurak belum mengenal adaya ajaran agama jadi masyarakat di Dusun Temurak masih menganut kepercayaan kepada roh-roh nenek moyang atau kepercayaan animisme.Proses pelaksnaan tradisi Umpan Kampung terdiri dari mengadakan musyawarah yang diadakan di rumah dukun, kemudian mempersiapkan tempat pelaksanaan tradisi yang berada di Pulau Belumbak, orang-orang yang terlibat dalam pelaksanaan tradisi Umpan Kampung yakni dukun, pewawang, dan masyarakat, dilanjutkanktetahap persiapan yaitu menyiapkan alat-alat dan bahan (peribuh) yang digunakan dalam tradisi Umpan Kampung. Tahap pelaksanaan kegiatan tradisi Umpan Kampung yang dilaksanakan di Pulau Belumbak. Tradisi Umpan Kampung terdiri nilai-nilai luhur yang melekat dalam proses pelaksanaan tradisi Umpan Kampung yang terdiri dari nilai musyawarah, nilai kebersamaan, nilai gotong royong, nilai solidaritas, dan nilai religius.

\section{Saran}

Berdasarkan kesimpulan diatas, maka peneliti menyampaikan saran-saran sebagai berikut bagi pemerintah daerah Pihak kecamatan Meliau seharusnya lebih intensif lagi dalam membina dan menjaga keberadaan tradisi Umpan Kampung. sehingga memberikan dukungan berupa bantuan moril maupun materil agar nantinya pelaksanaan tradisi Umpan Kampung bisa berjalan dengan lancar. Saran bagi masyarakat Masyarakat Dusun Temurak harus bisa menjaga dan melestarikan peningglaan budaya tradisi Umpan Kampung, agar bisa dikenal oleh masyarakat dan dilestarikan oleh generasi peneurs yang ada, sehingga partisipasi masyarakat dalam kelestarian kebudayaan ini sangat mempunyai peranan pada eksistensi perayaan tradisi Umpan Kampung. Saran bagi peneliti Kepada peneliti agar dapat mempelajari kebudayaan di masing-masing daerahnya, sehingga menambah wawasan dan mencerdaskan bangsa.

\section{DAFTAR RUJUKAN}

Aminuyati. (2019). Pengantar Ilmu Pengetahuan Sosial. Pontianak: Pustaka Rumah Alloy (PRA)

Darwis.R. (2017). Tradisi Ngaruwat Bumi Dalam Kehidupan Masyarakat (Studi Deskriptif Kampung Cihideung Girang Desa Sukakerti Kecamatan Cisalak Kabupaten Subang). Jurnal Studi Agamaagama dan Lintas Budaya. Vol2(1), 75-83. Diunduh di https://journal.uinsgd.ac.id/index.p $\mathrm{hp} /$ Religious/article/view/2361

Herabudin. (2015). Pengantar Sosiologi. Bandung: CV PUSTAKA SETIA.

Juliana. (2017). Tradisi Mappasoro Bagi Masyarakat Desa Barugariattang Kecamatan Bulukumpa Kabupaten Bulukumpa. SKRIPSI. UIN Alauddin Makasar. diakses pada tanggal 13 oktober 2020. http://repositori.uinalauddin.ac.id/id/eprint/4270

Nurfadillah. (2014). Persepsi Masyarakat Terhadap Tradisi Massempe Didesa Mattoanging Kecamatan Tellu Siattinge Kabupaten Bone. SKRIPSI. UIN Alauddin Makasar. diakses pada tanggal 13 oktober $2020 . \quad \mathrm{http} / / /$ repositori.uinalauddin.ac.id/id/eprint/6835

Read,D., \& Andersson,C.(Eds). (2019). Cultural Complexity and Complexity Evolution. Department of Space, Earth and EnvironmentChalmers University of Technology. Jurnal of Adaptive Behavior, Vol.28(5), 329-358. DOI:10.1177/1059712318822298. 
Sosial Khatulistiwa: Jurnal Pendidikan IPS

Vol. 01, No. 01, Agustus 2021, p. 35 - 44

Soelaeman, M. (2010). Ilmu Sosial Dasar.

Bandung : PT.Refika Aditama.

Sugiyono. (2020). Metode Penelitian

Kualitatif. Bandung : CV Alfabeta

Sugiyono. (2019). Metode Penelitian

Kuantitatif Kualitataif Dan $R \& D$.

Bandung : CV Alfabeta 